\title{
Ecological profiles of wetland plant species in the northern Apennines (N. Italy)
}

\author{
Alessandro PETRAGLIA and Marcello TOMASELLI* \\ Dipartimento di Biologia Evolutiva e Funzionale, Università di Parma, Parco Area delle Scienze 11/A, I-43100 Parma, Italy \\ *e-mail corresponding author: tomasell@unipr.it
}

\begin{abstract}
Eighteen selected species occurring in the wetlands of the northern Apennines were studied by the ecological profile method. By this method, it is possible to identify the ecological factors mostly influencing species distribution within a particular vegetation. Moreover, it is possible to evaluate both ecological amplitude and ecological preferences of species. Ecological profiles were built for three factors (altitude, $\mathrm{pH}$ and electrical conductivity) from a data set of 265 phytosociological relevés, used for altitude, and from a set of 92 measures, carried out in selected sites, for idrochemical variables. By numerical classification, based on chord distance and minimum variance, the ecological species groups for each factor were individuated. Subsequently, they were ordered by correspondence analysis for detecting relationships between ecological groups and classes of factors. By applying a goodness-of-fit test to ecological profiles, the species significantly deviating from uniformity were detected. They can be regarded as indicators for the corresponding ecological factor. We found seven indicator species for altitude (Carex nigra, C. rostrata, Juncus filiformis, J. alpino-articulatus, Eriophorum latifolium, E. angustifolium and Warnstorfia exannulata), four indicator species for electrical conductivity (Campylium stellatum, Carex tumidicarpa, Eriophorum latifolium and Juncus alpino-articulatus) and one indicator species for $\mathrm{pH}$ (Sphagnum capillifolium). The ecological profiles of the wetland species in the northern Apennines were compared with those reported in literature for the same species from the Alps (namely Dolomites). In this way, a certain degree of ecological shift in several wetland species of the northern Apennines was documented. For altitude, it is possible to explain the shift considering the reduced elevational amplitude of northern Apennine wetlands with respect to those of the Alps. For $p H$, Sphagnum capillifolium occurs in less acidic habitats than in the Alps, probably due to the absence of ombrotrophic mires, and Viola palustris occurs mostly in neutro-basiphytic habitats. Some hypotheses to explain the ecological behaviour of this last species were proposed.
\end{abstract}

Keywords: ecological profiles, statistical multivariate analysis, indicator species, mountain wetlands, northern Apennines

\section{INTRODUCTION}

The analysis of species-environment relationships and the identification of indicator species are traditional activities in ecology. Bioindicators can be defined as species whose presence or abundance readily reflect some measure of the character of the habitat within which they are found (McGeoch \& Chown 1998). Besides its prime importance as a research tool in autoecology, the quantification of species-environment relationships recently gained importance as a tool to control the distribution of species and communities, to test biogeographical hypotheses, or to set up conservation priorities (Guisan \& Zimmermann 2000).

In recent years, there has been an increasing interest in defining the relationships between the occurrence of plant species and site conditions, using response modelling. The primary aim of most studies is to acquire more insight into the distribution of species along a gradient, to determine which variables affect the presence or absence of species and to investigate in what way the prediction of species could be improved (Austin 1990; Yee \& Mitchell 1991; Huisman et al. 1993; Austin \& Gaywood 1994).

In plant ecology one of the method currently used by european scientists to investigate the species-environment relationships is the ecological profile method
(Gounot 1958, 1969; Godron 1966, 1968; Guillerm 1971). By this method, it is possible to transform data resulting from vegetation analyses and environmental measures into ecological profiles. The analysis of ecological profiles by information theory allows to test the predictivity of ecological factors and the indication power of species. In other words, this method allows to evaluate the affinity and significance of the association between probability of species occurrence and environmental factors (Daget \& Godron 1982).

The ecological profile method is a powerful instrument to recognize indicator species and it has been tested and used by several authors in different habitats (Gounot 1958; Guillerm 1969a, 1969b; Ferrari \& D’Antuono 1983; Guillerm \& Sutisna 1983; Haury 1995; Vasconcellos et al. 1999; Devineau 2001; Zas \& Alonso 2002). Nevertheless, this method has been hitherto scarcely employed to study mountain wetland vegetation and there are few works concerning the ecological profiles of the species growing on these habitats (Gerdol \& Bragazza 1994; Gerdol \& Tomaselli 1997).

In particular, there are no works focused on the wetland vegetation of the northern Apennines, in spite of its phytogeographic and conservation interest, due to the occurrence of boreal species lying at the very southern border of their distributional area in Europe. Some of these species have their ecological space dramatically 


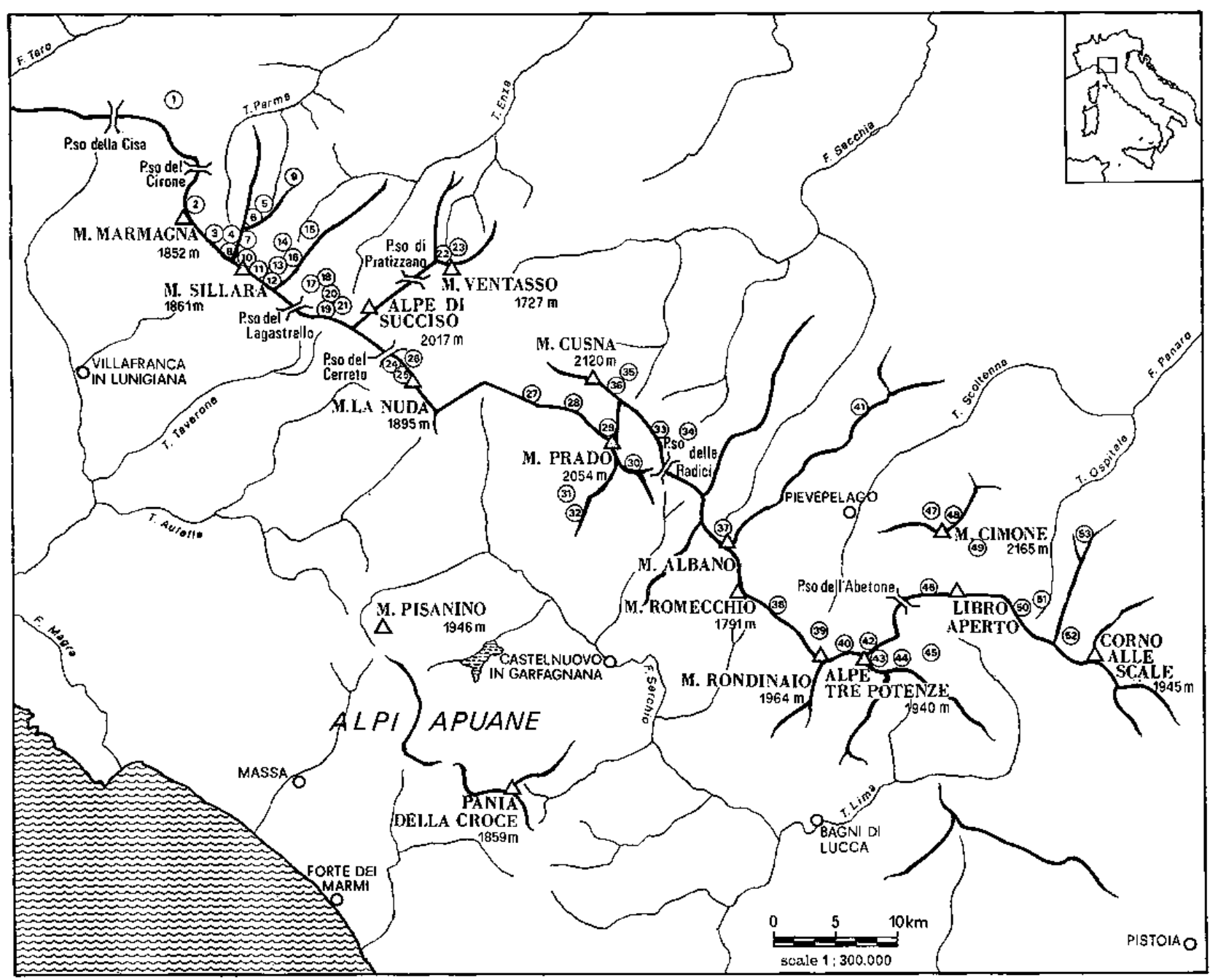

Fig. 1. Map of the study area. Figures indicate the wetlands surveyed.

reduced with respect to northern regions, whereas others have better opportunities to extend their ecological niche as a consequence of the floristic impoverishment (Gerdol \& Tomaselli 1993).

The present paper is a first attempt to define the ecological profiles of wetland vascular plants and bryophytes in this mountain area, characterised by a scarcity of studies on wetland plant ecology. Moreover, the paper aims at: i) identifying local indicator species useful in the fields of nature monitoring, conservation and management; ii) verifying and quantifying shifts in the ecological optima of wetland species with respect to northern regions, particularly to the Dolomites studied by Gerdol \& Tomaselli (1997).

\section{STUDY AREA}

The study area corresponds to the sector of the northern Apennines comprised between Cisa Pass and the valley of Reno river. This sector of the Apennines, nearly $150 \mathrm{~km}$ long, separates the Po plain northwards from the Italian peninsula southwards and has only few summits exceeding $2000 \mathrm{~m}$ (Fig. 1).

The geological substratum mainly consists of thickbedded turbiditic sandstones and marls (upper Oligocene - lower Miocene), corresponding to the "Macigno" formation (Dallan Nardi \& Nardi 1974). The gently shelving northern slope is characterized by glacial landforms originated during Pleistocene (Losacco 1982), but still evident nowadays. In contrast, the southern slope is much steeper and shows only poor traces of glacial morphology.

The climate in the study region can be defined as temperate montane. At $1000 \mathrm{~m}$ the mean annual temperature is $c a 9{ }^{\circ} \mathrm{C}$, that of January $c a 1^{\circ} \mathrm{C}$ and that of July $18{ }^{\circ} \mathrm{C}$. On the summit (M. Cimone, $2165 \mathrm{~m}$ ) the mean annual temperature is $2.1^{\circ} \mathrm{C}$, that of January -4.3 ${ }^{\circ} \mathrm{C}$ and that of July $10.3{ }^{\circ} \mathrm{C}$. Precipitation is more abundant on the southern slope, influenced by the Tyrrhenian Sea, than on the more continental northern slope. At $1000 \mathrm{~m}$ the mean annual rainfall is $c a 2300 \mathrm{~mm}$ on the $\mathrm{S}$ 
Tab. 1. Numbers from I to VI represent the class intervals for each factor considered, as defined for ecological profiles analysis.

\begin{tabular}{lcccccc}
\hline Class Intervals & I & II & III & IV & V & VI \\
\hline Altitude $(m$ a.s.1.) & $\leq 1300$ & $1301-1400$ & $1401-1500$ & $1501-1600$ & $1601-1700$ & $>1700$ \\
pH & $\leq 5.10$ & $5.11-5.70$ & $5.71-6.30$ & $6.31-6.90$ & $>6.90$ & - \\
Conductivity $\left(\mu \mathrm{S} \mathrm{cm}^{-1}\right)$ & $\leq 40$ & $41-80$ & $81-120$ & $>120$ & - & - \\
\hline
\end{tabular}

slope and $c a 1400 \mathrm{~mm}$ on the $\mathrm{N}$ slope. On the summit there are only $750 \mathrm{~mm}$.

Wetlands in the northern Apennines usually represent more or less evolved dynamics stages in the fillingup process of lakes. Most of these lakes are clearly related to glacial morphology, for being located either at the bottom of glacial cirques or between morainic archs (Carton \& Panizza 1988). There are, moreover, small shallow pools originated by differential erosion of looser nuclei of sandstone. A big majority of wetlands in the northern Apennines are located above $1000 \mathrm{~m}$ and specially around $1500 \mathrm{~m}$, at the mean altitude of the bottom of glacial cirques, inside a vegetation belt (montane belt) dominated by Fagus sylvatica forests.

The wetland vegetation in the northern Apennines includes eighteen different plant communities (Gerdol \& Tomaselli 1993), belonging to the following main vegetation typologies: 1) water-plant communities; 2) riparian helophytic communities; 3) mire vegetation with fens, Sphagnum mats and Sphagnum hummocks; 4) wet-meadow communities.

\section{MATERIALS AND METHODS}

The data set for this paper, derived from Gerdol \& Tomaselli (1993), consists of 265 phytosociological relevés, taken from 53 different sites and of 92 water chemistry measures (of $\mathrm{pH}$ and electrical conductivity), carried out with portable instruments at some selected relevé sites.

Data processing was carried out by means of the ecological profile method (Daget \& Godron 1982). The following three ecological factors, affecting distribution of plant species in mountain wetlands according literature (e.g., Dierssen 1982, 1996; Sjörs 1983; Malmer 1986; Økland 1990), were considered for the calculation of the ecological profiles: i) altitude, reflecting the temperature gradient; ii) $\mathrm{pH}$; iii) electrical conductivity. The data set for ecological profiles comes from 265 relevés for altitude, and from 92 relevés for $\mathrm{pH}$ and electrical conductivity.

The ecological profiles were calculated for only 18 species, selected choosing, among the species belonging to the characteristic combination (Braun-Blanquet 1964) of all wetland vegetation units, only the ones occurring in more than $7 \%$ of the whole relevé set.

Each ecological factor was subdivided into different numbers of classes of equal amplitude. Intervals of factor classes are reported in table 1 . In order to obtain an estimate of the degree of information provided by the factors in relation to the species as a group, the entropy factor was expressed in terms of the mean of the joint species-factor information. The factors with greatest mutual species-factor information values are the "effective" ones (Daget \& Godron 1982). Joint species-factor information and entropy factor were calculated as in Daget \& Godron (1982).

Corrected frequencies (CF) were calculated for the 18 selected species as follows:

$$
C F=\frac{U(K) / R(K)}{U(S) / N}
$$

where $U(K)=$ occurrences of species $S$ in factor class $K$, $U(S)=$ total number of occurrences of species $S, R(K)=$ number of samples for factor class $K$ and $N=$ total number of samples. The degree of departures of $C F$ values from 1 indicates the level of response to that ecological factor. Values above 1 indicate a preference and values below 1 indicate a rejection.

A multivariate statistical approach was employed to individuate ecological species groups, by classifying and ordering the ecological profiles for each factor. Classification was performed by the minimum increase of sum of square agglomeration based on the chord distance (Orloci 1978), ordination by the correspondence analysis (Benzecri 1973). For computations the package SYNTAX 5.0 (Podani 1993) was used.

The local indicator species were detected applying the Kolmogorov-Smirnov goodness-of-fit testing to the ecological profiles in order to investigate whether the observed distribution of a species within the classes of each factor showed significant departures from the distribution expected under the null hypothesis of uniformity.

The nomenclature of species follows Pignatti (1982) for vascular plants, with the exception of Carex nigra (L.) Richard (Chater 1980), Corley et al. (1981) and Corley \& Crundwell (1991) for bryophytes.

\section{RESULTS}

The plot of factor entropies against mean mutual species-factor information (Fig. 2) points up that each ecological factor appears adequately sampled and it plays a discriminant role on species distribution. In particular, altitude and electrical conductivity appear as more efficient than $\mathrm{pH}$ for predicting species distribution. 


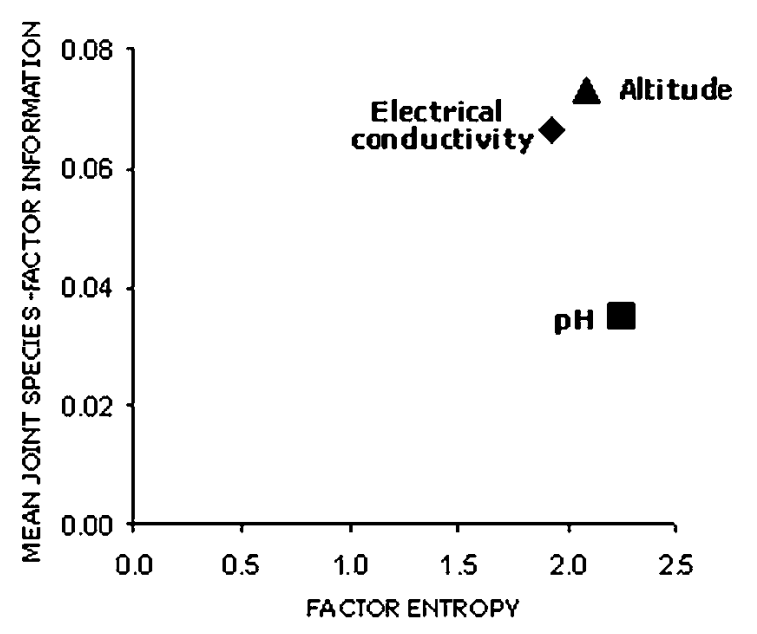

Fig. 2. Plot of mean joint species-factor information against entropy.

The ecological profiles of 18 species, giving a readily interpretable information about ecological amplitude of species and allowing to underscore their preferences for the factor, are reported in figure 3.

The ordination of ecological species groups, obtained for each factor by the classification of the ecological profiles, allows to point out some groups of species gravitating around a particular factor class and arranged along the first two ordination axes according to the gradients of the factors (Fig. 4).

For altitude three ecological species groups are clearly separated in the graph (Fig. 4a). The group composed by Carex rostrata, C. tumidicarpa, Juncus alpino-articulatus, Eriophorum latifolium and Menyanthes trifoliata, is centered around the lowest classes of the factor and it occurs preferentially at low altitudes, below $1400 \mathrm{~m}$. A second species group numerically richer and composed by Sphagnum capillifolium, $S$. palustre, S. subsecundum, Eriophorum angustifolium, Carex irrigua, Campylium stellatum and Trichophorum alpinum, shows preferences for altitudes between 1400 and $1600 \mathrm{~m}$. A third group of species, consisting of Warnstorfia exannulata, Juncus filiformis, Viola palustris, Carex stellulata, C. nigra and Parnassia palustris occurs preferentially above $1600 \mathrm{~m}$.

Also for $\mathrm{pH}$ it is possible to point up three species groups (Fig. 4b). The first group, formed by Sphagnum capillifolium and $S$. palustre, shows high preferences for the lowest classes of the factor, under a $\mathrm{pH}$ value of 5.70. A second group of species, composed by the corebulk of the species occurring in the northern Apennine wetlands, occurs preferentially at $\mathrm{pH}$ values ranging from 5.10 to 6.30. Furthermore, a third species group, consisting of Eriophorum latifolium, Campylium stellatum, Carex tumidicarpa, Juncus alpino-articulatus, Parnassia palustris and Viola palustris, show preferences for $\mathrm{pH}$ values above 6.30 .
Only two species groups can be clearly separated along a gradient of electrical conductivity (Fig. 4c). The first one, composed by Sphagnum capillifolium, $S$. palustre, S. subsecundum, Eriophorum angustifolium, Menyanthes trifoliata and Trichophorum alpinum is linked to values of electrical conductivity below $120 \mu \mathrm{S}$ $\mathrm{cm}^{-1}$. Sphagnum capillifolium and Menyanthes trifoliata are centered in the second class (between 40-80 $\mu \mathrm{S}$ $\mathrm{cm}^{-1}$ ). whereas Sphagnum palustre, S. subsecundum, Eriophorum angustifolium and Trichophorum alpinum occur preferentially between 40 and $120 \mu \mathrm{S} \mathrm{cm}^{-1}$. The second group of species, composed by Carex nigra, $C$. rostrata, C. stellulata, C. irrigua, C. tumidicarpa, Parnassia palustris, Eriophorum latifolium, Juncus alpinoarticulatus, Campylium stellatum and Viola palustris, occurs preferentially above $80 \mu \mathrm{S} \mathrm{cm} \mathrm{cm}^{-1}$. Among these species, a subgroup, composed by Parnassia palustris, Eriophorum latifolium, Carex tumidicarpa, Juncus alpino-articulatus, Campylium stellatum and Viola palustris, can be separated. This subgroup is centered around the highest class of the factor, above $120 \mu \mathrm{S}$ $\mathrm{cm}^{-1}$. Furthermore, Warnstorfia exannulata and Juncus filiformis were not included within a specific group, for having a bimodal distribution with two different peaks at the extreme classes (Fig. 3).

The results of Kolmogorov-Smirnov test show that some ecological profiles deviate significantly from uniformity. Observed frequencies are significantly different $(p<0.05)$ from corresponding expected frequencies for 7 species in the ecological profiles concerning altitude, for 4 species in those concerning electrical conductivity and for 1 species only in those concerning pH (Fig. 3).

Concerning altitude, three species (Carex rostrata, Juncus alpino-articulatus and Eriophorum latifolium), mostly occurring below $1400 \mathrm{~m}$, form a thermophilous species group; whereas the species mostly sampled above $1600 \mathrm{~m}$ (Carex nigra, Juncus filiformis and Warnstorfia exannulata) are clearly cryophilous. Eriophorum angustifolium, mostly occurring between 1400 and $1600 \mathrm{~m}$, is significantly correlated to intermediate temperature conditions.

Campylium stellatum, Carex tumidicarpa, Eriophorum latifolium and Juncus alpino-articulatus, mostly occurring at values of electrical conductivity above 80 $\mu \mathrm{S} \mathrm{cm} \mathrm{cm}^{-1}$, can be regarded as good indicators for the highest trophic levels occurring in the peatlands of the northern Apennines. In the ecological profiles concerning $\mathrm{pH}$, only the observed frequencies of Sphagnum capillifolium deviate significantly from uniformity; therefore, this species can be considered a good indicator for $\mathrm{pH}$ values lower than 5.70.

\section{DISCUSSION}

Ten species (7 vascular plants and 3 bryophytes) resulted mostly predictive with respect to the variation of habitat factors in the wetlands of the northern Apennines. 
Eriophorum latifolium

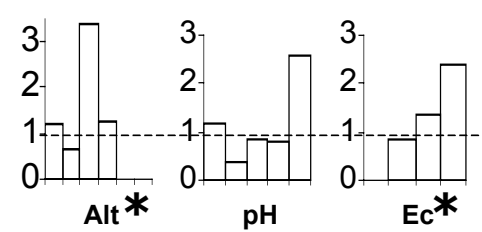

Carex tumidicarpa

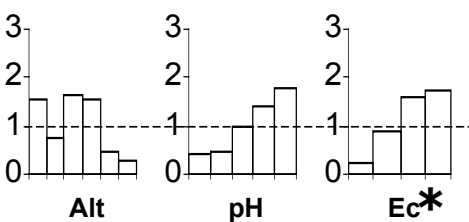

Juncus alpino-articulatus

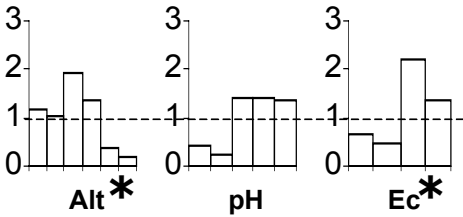

\section{Campylium stellatum}

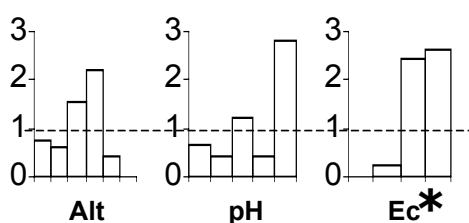

\section{Carex rostrata}

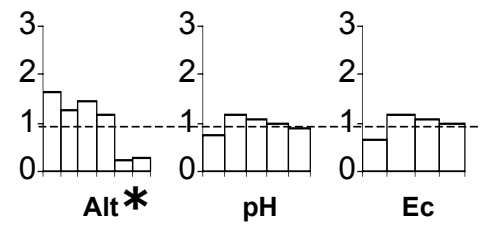

Menyanthes trifoliata

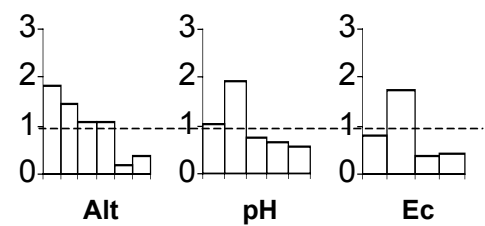

Sphagnum capillifolium

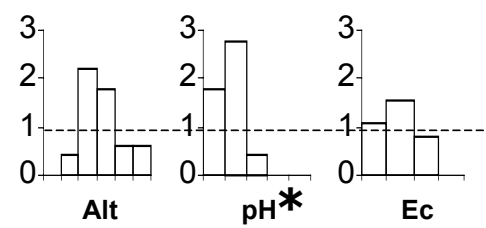

Sphagnum palustre

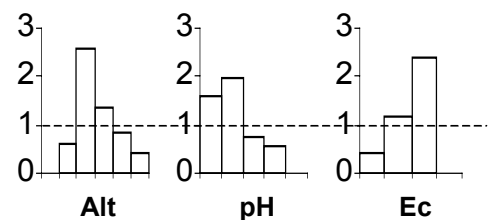

Sphagnum subsecundum

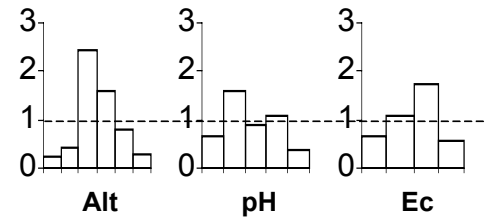

Eriophorum angustifolium

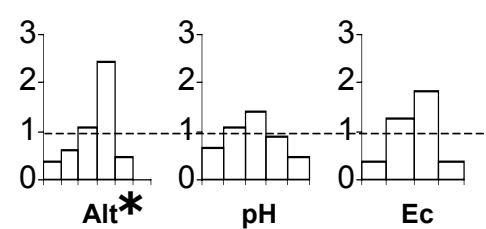

Carex irrigua

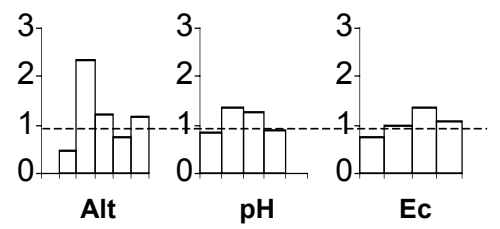

Trichophorum alpinum

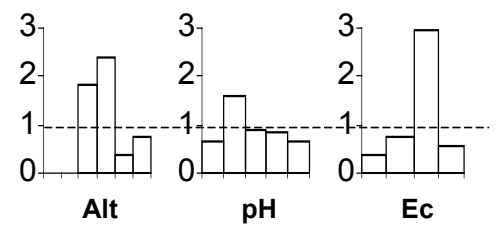

Warnstorfia exannulata

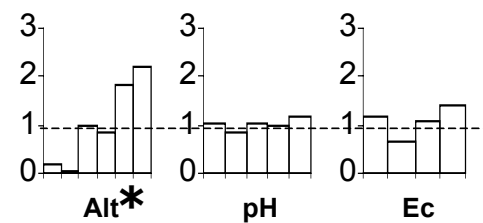

Juncus filiformis

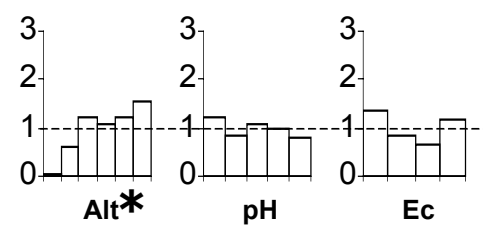

\section{Viola palustris}

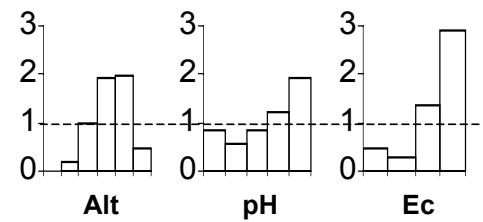

Carex nigra

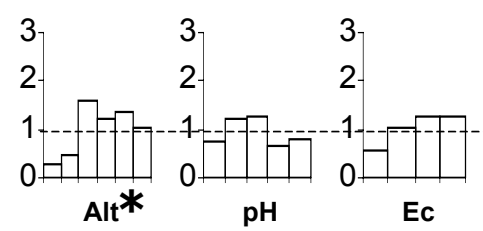

\section{Carex stellulata}

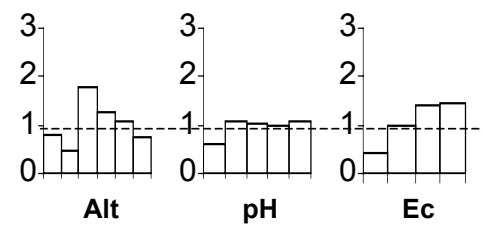

\section{Parnassia palustris}

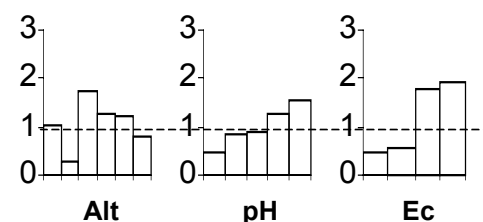

Fig. 3. Ecological profiles with respect to altitude, $\mathrm{pH}$ and conductivity. Each factor was divided into a different number of classes of equal value as reported in table 1 . Asterisks indicate significantly non-uniform distribution $(p<0.05)$ with respect to those factors. Profile values of 1 indicate uniform distribution; values greater than 1 indicate preference. 


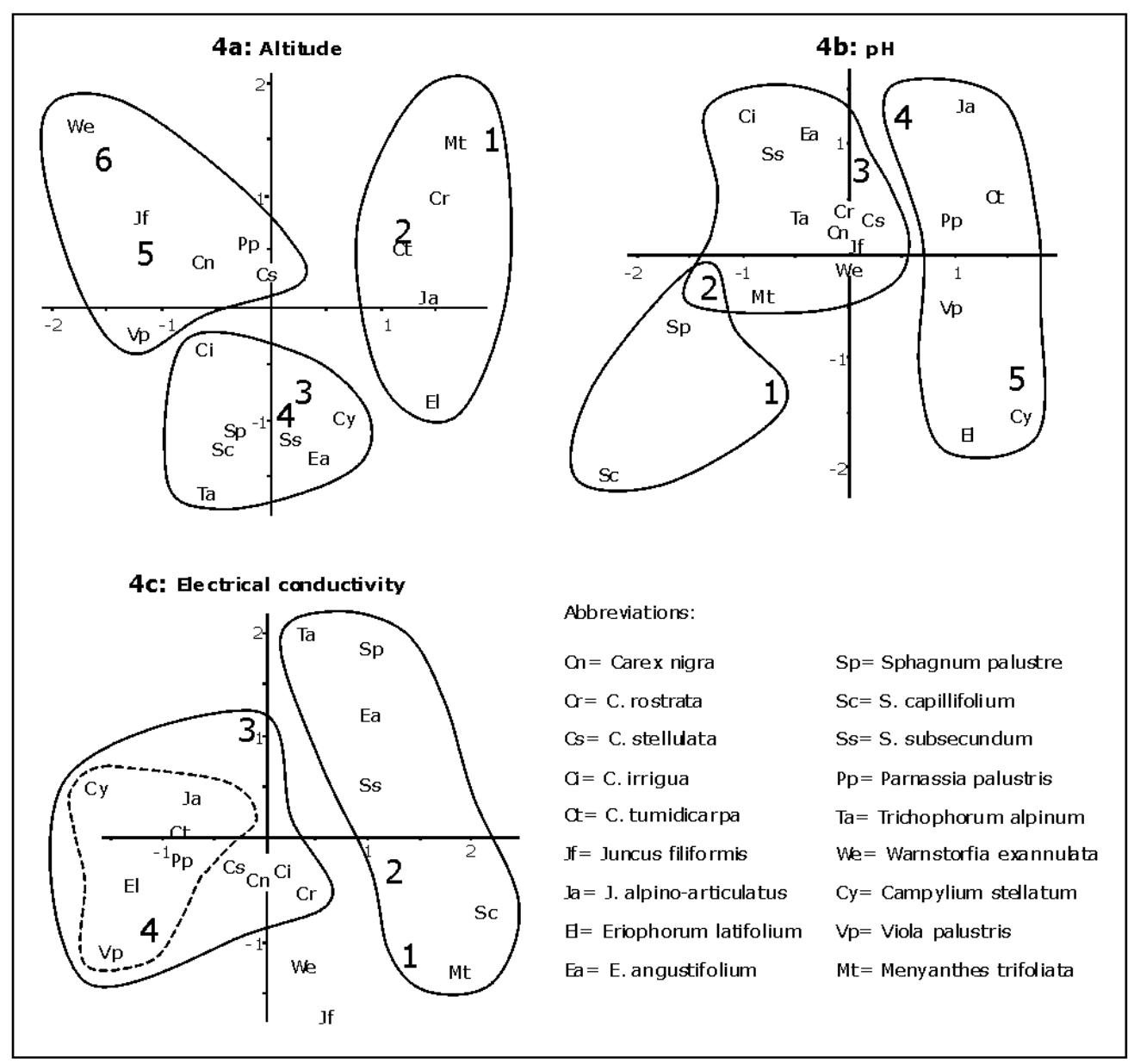

Fig. 4. Species groups gravitating around a particular factor class (bold numbers) and arranged along the first two ordination axes according to the gradients of the factors. Each ecological factor was subdivided into different numbers of classes of equal amplitude as reported in table 1 .

These wetlands are spread within a relatively broad altitudinal range (from 1100 to $1800 \mathrm{~m}$ ) and, therefore, the number of species, whose distribution is significantly correlated with altitude, is particularly high.

On the countrary, only one species resulted significantly correlated with $\mathrm{pH}$ variation. In the northern Apennine wetlands, the variation range of this parameter is, in fact, markedly narrower with respect to that of the altitude. That is due to two fundamental reasons: i) in the summits of the northern Apennines geological substratum consists of lime-poor rocks; ii) ombrotrophic mires (bogs) lack at all in this area and, moreover, among minerotrophic mires (fens), the greatest number is represented by moderate-rich fens.

For the electrical conductivity, the number of indicator species (4) is intermediate. The significant correlation between the distribution of these species and the highest classes of this parameter is not a surprising result. Eriophorum latifolium, Campylium stellatum and Juncus alpino-articulatus occur, in fact, very frequently in the Alps within rich calcareous fens (Steiner 1992;
Gerdol 1994; Gerdol \& Tomaselli 1997). On the other hand, rich fens lack at all in the northern Apennines (Gerdol \& Tomaselli 1993) and, consequently, the occurrence of this species presumably reflects small-scale nutrient distribution patterns occurring in some mires.

Vegetation patterns in boreal and north-temperate peatlands are strongly affected by a "poor-rich in nutrients" gradient (Sjörs 1948). The poor-rich direction of variation in vegetation was paralleled by a general increase in ion concentration in peatland water (Du Rietz 1949; Witting 1949, Gorham, 1956; Jeglum 1971; Vitt \& Chee 1990). Calcium, magnesium and sodium are most responsible for this increase, reflected by electrical conductivity measures.

The occurrence of rich-fen species within the acidophytic mires of the northern Apennines is presumably determined by small scale poor-rich gradients, linked to surface microtopography.

The second aim of this work was to verify shifts in the ecological optima of wetland species occurring in the northern Apennines. No data are presently available 
for electrical conductivity, but for $\mathrm{pH}$ and altitude it is possible to verify some ecological shifting, comparing our profiles with those reported by Gerdol \& Tomaselli from the Dolomites (1997).

Eriophorum angustifolium, E. latifolium and Juncus alpino-articulatus occur in the northern Apennines at lower altitudes than in the Alps. Concerning $\mathrm{pH}$, four species show a certain degree of shifting in their ecological profiles. In the northern Apennines, the profiles of Menyanthes trifoliata and Trichophorum alpinum are shifted towards lower values, corresponding to more acidic habitats, while those of Sphagnum capillifolium and Viola palustris show an opposite behaviour.

The ecological shifting in altitude and towards more acidic habitats can be explained by the absence in the northern Apennines of suitable habitats for these species (mires above $1800 \mathrm{~m}$ and rich fens). Also for Sphagnum capillifolium the shift in the ecological optimum is presumably due to the absence of suitable habitats, such as ombrotrophic mires and to the rarity of intermediate mires with Sphagnum hummocks in the northern Apennines. The shift concerning $\mathrm{pH}$ range of Viola palustris can be hardly explained. A first hypothesis could be the occurrence, at the southern distributional border of this species, of an ecotype having different ecological requirements. According a second hypothesis, the ecological profile could be conditioned by modifications in the competitive equilibria with other species.

\section{REFERENCES}

Austin, M.P. 1990. Community theory and competition in vegetation. In: Grace, J.B. \& Tilman, D. (Eds), Perspectives on Plant Competition. Academic Press, San Diego, CA: 215-238.

Austin, M.P. \& M.J. Gaywood. 1994. Current problems of environmental gradients and species response curves in relation to continuum theory. J. Veg. Sci., 5: 473-482.

Benzecri, J.P. 1973. L'Analyse des Données. 2: L'Analyse des Correspondances. Dunod, Paris: $618 \mathrm{pp}$.

Braun-Blanquet, J. 1964. Pflanzensoziologie. 3rd ed., Springer, Wien: $865 \mathrm{pp}$.

Carton, A. \& M. Panizza. 1988. Il paesaggio fisico dell'alto Appennino emiliano. Grafis Edizioni, Bologna: 182 pp.

Chater, A.O. 1980. Carex L. In: Tutin, T.G., V.H. Heywood, N.A. Burges, D.H. Valentine, S.M. Walters \& D.A. Webb (Eds), Flora Europaea. Cambridge Univ. Press, 5: 290-313.

Corley, M.V.F. \& A.C. Crundwell. 1991. Addition and amendments to the mosses of Europe and the Azores. $J$. Bryol., 16: 337-356.

Corley, M.V.F., A.C. Crundwell, R. Düll, M.O. Hill \& A.J.E. Smith. 1981. Mosses of Europe and the Azores; an annotated list of species, with synonyms from recent literature. J. Bryol., 11: 609-689.

Daget, P. \& M. Godron. 1982. Analyse fréquentielle de l'ecologie des espèces dans les communautés. Masson, Paris: $178 \mathrm{pp}$.

Dallan Nardi, L. \& R. Nardi. 1974. Schema stratigrafico e strutturale dell'Appennino settentrionale. Mem. Acc. Lunig. Sc., 12: 1-212.

Devineau, J.L. 2001. Woody species as soil indicators in some savannas and fallows of West Burkina Faso. Phytocoenologia, 31: 325-351.
Dierßen, K. 1982. Die wichtigsten Pflanzengesellschaften der Moore NW-Europas. Conservatoire et Jardin Botanique, Genève: $382 \mathrm{pp}$.

Dierßen, K. 1996. Vegetation Nordeuropas. Ulmer, Stuttgart: $838 \mathrm{pp}$.

Du Rietz, G. E. 1949. Huvudenheter och huvudgränser i Svensk myrvegetation. Svensk. Bot. Tidskr., 43: 274-309.

Ferrari, C. \& L.F. D'Antuono. 1983. Specie ed associazioni mioalofile in suoli argillosi dell'Appennino emiliano: contributo alla caratterizzazione ecologica. In: Ferrari, C., S. Gentile, S. Pignatti \& E. Poli Marchese (Eds), Le comunità vegetali come indicatori ambientali. Soc. It. di Fitosociologia \& Regione Emilia-Romagna, Bologna, Italia: 55-80.

Gerdol, R. 1994. The vegetation of wetlands in the southern Carnian Alps (Italy). Gortania - Atti Mus. Friul. Storia Nat., 15: 67-107.

Gerdol, R. \& L. Bragazza. 1994. The distribution of Sphagnum species along an elevational gradient in the southern Alps (Italy). Bot. Helv., 104: 93-101.

Gerdol, R. \& M. Tomaselli. 1993. The vegetation of wetlands in the northern Apennines (Italy). Phytocoenologia, 21: 421-469.

Gerdol, R. \& M. Tomaselli. 1997. Vegetation of wetlands in the Dolomites. Dissertationes Botanicae, 281. Cramer, Stuttgart: $197 \mathrm{pp}$.

Godron, M. 1966. Application de la théorie de l'information à l'étude de l'homogénéité et de la structure de la végétation. Oecol. Plant., 2: 187-197.

Godron, M. 1968. Quelques applications de la notion de fréquence en écologie végétale (recouvrement, information mutuelle entre espéces et facteurs écologiques, échantillonnage). Oecol. Plant., 3: 185-212.

Gorham, E. 1956. On the chemical composition of some waters from the Moor House nature reserve. J. Ecol., 44: 375-382.

Gounot, M. 1958. Contribution à l'étude des groupments végétaux massicoles et rudéraux de Tunisie. Ann. Inst. Natl. Rech. Agron. Tunisie, 31: 1-282.

Gounot, M. 1969. Méthodes d'études quantitative de la végétation. Masson et Cie, Paris: 314 pp.

Guillerm, J.L. 1969a. Relations entre la végétation spontanée et le milieu dans les terres cultivées du Bas Languedoc. Thèse 3ème cycle. Ecologie. Fac. Sc. Montpellier, 165 pp.

Guillerm, J.L. 1969b. Les milieux cultivés a Chondrilla juncea dans le Bas Languedoc. C.N.R.S.-C.E.P.E., Doc. 49: 28 pp.

Guillerm, J. L. 1971. Calcul de l'information fournie par un profile écologique et valeur indicatrice des espèces. Oecol. Plant., 6: 209-225.

Guillerm, J.L. \& M. Sutisna. 1983. Caractérisation écologique des adventices des rizières en Camargue (France). In: Ferrari, C., S. Gentile, S. Pignatti \& E. Poli Marchese (Eds), Le comunità vegetali come indicatori ambientali. Soc. It. di Fitosociologia \& Regione Emilia-Romagna, Bologna, Italia: 33-53.

Guisan, A. \& N.E. Zimmermann. 2000. Predictive habitat distribution models in ecology. Ecol. Model., 135: 147-186.

Haury, J.1995. Patterns of macrophyte distribution within a Breton brook compared with other study scales. Landscape Urban Plan., 31: 349-361.

Huisman, J., H. Olff \& L.F.M. Fresco. 1993. A hierarchical set of models for species response analysis. J. Veg. Sci., 4: 37-46.

Jeglum, J.K. 1971. Plant indicators and water levels in peatlands at Canada Lake, Saskatchewan. Can. J. Bot., 57: 2283-2317.

Losacco, V. 1982. Gli antichi ghiacciai dell'Appennino settentrionale. Studio morfologico e paleogeografico. Atti Soc. Nat. Modena, 113: 1-224.

Malmer, N. 1986. Vegetational gradients in relation to environmental conditions in northwestern European mires. Can. J. Bot., 64: 375-383. 
Mcgeoch, M.A. \& S.L. Chown. 1998. Scaling up the value of bioindicators. Trend Ecol. Evol., 13: 46-47.

Økland, R.H. 1990. A phytoecological study of the mire Northern Kisselbergmoosen, SE Norway. II. Identification of gradients by detrended (canonical) correspondence analysis. Nord. J. Bot., 10: 79-108.

Orloci, L. 1978. Multivariate analysis in vegetation research. Junk, The Hague: 276 pp.

Pignatti, S. 1982. Flora d'Italia. Edagricole, Bologna, 3 vols: $2302 \mathrm{pp}$.

Podani, J. 1993. SYN-TAX version 5.0 Computer Programs for Multivariate Data Analysis in Ecology and Systematics. Scientia Publishing, Budapest: 104 pp.

Sjörs, H. 1948. Myrvegetation i Bergslagen. Acta Phytogeogr. suec., 21: 1-299.

Sjörs, H. 1983. Mires of Sweden. In: Gore, A.J.P. (Ed.), Mires: swamp, bog, fen, and moor. Ecosystems of the worlds. Elsevier, Amsterdam, 4B: 69-94.

Received:February 2003

Accepted: April 2003
Steiner, G. M. 1992. Österreichischer Moorschutzkatalog. Moser, Graz: 509 pp.

Vasconcellos, T., M. Tavares \& N. Gaspar. 1999. Aquatic plants in the rice fileds ot the Tagus Valley, Portugal. Hydrobiologia, 415: 59-65.

Vitt, D.H. \& W.L. Chee. 1990. The relationships of vegetation to surface water chemistry in fens of Alberta, Canada. Vegetatio, 89: 87-106.

Witting, M. 1949. Kalciumhalten i några nordsvenska myrvatten. Svensk. Bot. Tidskr., 43: 715-739.

Yee, T.W. \& N.D. Mitchell. 1991. Generalized additive models in plant ecology. J. Veg. Sci., 2: 587-602.

Zas, R. \& M. Alonso. 2002. Understory vegetation as indicators of soil charachteristics in northwest Spain. For. Ecol. Manage., 171: 101-111. 